\title{
Access to Oral Health Actions According to Social and Individual Determinants
}

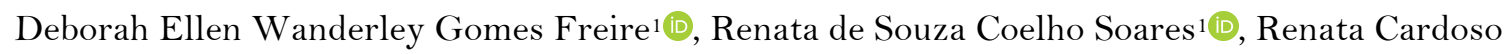

Rocha Madruga $^{2}\left(\mathbb{0}\right.$, Antares Silveira Santos ${ }^{2}\left(\mathbb{0}\right.$, Vanessa Alves de Medeiros ${ }^{2}(\mathbb{D}$, Allyson Martim

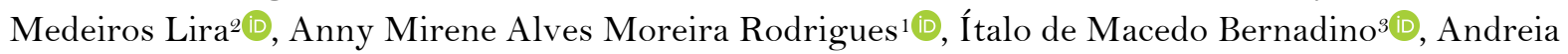
Medeiros Rodrigues Cardoso4(-1), Alessandro Leite Cavalcanti1 10

${ }^{1}$ Post-Graduate Program in Public Health, State University of Paraíba, Campina Grande, PB, Brazil.

${ }^{2}$ School of Dentistry, State University of Paraíba, Campina Grande, PB, Brazil.

${ }^{3}$ Post-Graduate Program in Dentistry, School of Dentistry, State University of Paraíba, Campina Grande, PB, Brazil.

${ }^{4}$ School of Dentistry, University Center of João Pessoa, João Pessoa, PB, Brazil.

Author to whom correspondence should be addressed: Deborah Ellen W. Gomes Freire, Mestrado em Saúde Pública, Universidade Estadual da Paraíba, Rua Domitila Cabral de Castro S/N, Central de Integração Acadêmica, sala 310 , Campina Grande, PB, Brazil. 58429-570. Phone: +55 83998879822. E-mail: ellenwg.d@,gmail.com.

Academic Editors: Alessandro Leite Cavalcanti and Wilton Wilney Nascimento Padilha

Received: 28 August 2019 / Accepted: 17 April 2020 / Published: 14 May 2020

How to cite this article: Freire DEWG, Soares RSC, Madruga RCR, Santos AS, Medeiros VA, Lira AMM, et al. Access to oral health actions according to social and individual determinants. Pesqui Bras Odontopediatria Clín Integr. 2020; 20:e5163. https://doi.org/10.1590/pboci.2020.081

\begin{abstract}
Objective: To investigate the socioeconomic, demographic and health needs that influence the access to oral health actions. Material and Methods: The sample consisted of 609 individuals who lived in areas covered by the Family Health Strategy in a city of the Northeast of Brazil. All individuals living in areas covered by the FHS with age equal to or higher than six years were included. Data analysis included descriptive, bivariate and multivariate statistics using decision-tree based Chi-squared automatic interaction detection (CHAID). Results: Most participants were female, aged 25-34 years, ranging in age from 6 to 87 years. It was evidenced that, among the studied variables, the most relevant for understanding the access to oral health actions were: age $(\mathrm{p}<0.001)$, educational level ( $\mathrm{p}$-value in Node $1=0.009$; $\mathrm{p}$-value in Node $7=$ $0.005)$ and self-perception of oral health $(\mathrm{p}=0.001)$. Conclusion: The results suggest that access to oral health actions is influenced by several social and individual factors, and it is marked by inequalities that favor individuals with higher educational level, better self-perception of oral health and lower age groups.
\end{abstract}

Keywords: Health Services Accessibility; Social Determinants of Health; Dental Health Services. 


\section{Introduction}

Access to health services, that is, the entry in the system, is one of the biggest challenges of public health, especially for the practice of equity. This is because, despite advances in recent years, inequalities present in Brazil are reflected in the precarious health conditions of the population, influencing access to health actions and services, including oral health [1-3]. Access to oral health services was guaranteed by the Brazilian Constitution of 1988, being recognized as an important component of an individual's health [4]. However, the expansion of these services in the Unified Health System (SUS) has faced barriers, such as scarce resources and limited supply [1].

The federal government has made efforts to prioritize and expand investments in oral health, for example, through the institution of the National Oral Health Policy (NOHP) and the increase of oral health teams in the Family Health Strategy (FHS) [5]. Notwithstanding the efforts, these actions did not bring effective changes in the work process, and have failed in the planning and organization of teams to determine priority groups $[6,7]$. Access to oral health services has not been completely consolidated in the country, and it is rather characterized by inequalities, where smaller age groups and higher social classes are prioritized [6,8$11]$.

Living and working conditions, as well as economic, social, cultural and behavioral factors can influence an individual's health status and the way the services are used, being defined, therefore, as social health determinants [12]. The literature points to several theoretical models that present the access and use of health services as a result of the interaction between social, individual and health system contextual determinants [13,14].

Previous studies made at national $[3,8,15,16]$ and regional level $[2,7,11]$ identified an association between access to oral health services and socioeconomic and demographic factors such as age, sex, marital status, educational level, income and health needs. Families in a situation of social exclusion are more vulnerable to precarious health conditions. Therefore, it is necessary that oral health actions be based on the evaluation of the living conditions and health of the population, allocating resources to groups with greater needs and difficulties of access [1,2].

After a critical review of the literature, it was observed that the majority of studies on access to oral health services $[2,8,15,16]$ analyzed the theme from the perspective of service utilization but did not investigate factors associated with full access to oral health actions, which include oral health promotion and prevention of oral diseases. This study has the goal of creating subsidies for analyzing the impacts, strengths and weaknesses of oral health policies in the country and contribute to the strategic planning and redesign of care practices and development of oral health actions.

Therefore, considering the importance of this type of assessment and its impact on directing oral health actions, the objective of this study was to investigate the socioeconomic and demographic factors and health needs that influence the access to oral health actions through the application of Multivariate Decision Tree modeling, which proved to be promising for public health approaches.

\section{Material and Methods}

Study Design and Sampling

This was a quantitative and analytical study with a cross-sectional and population-based design carried out in a city in the Northeast region of Brazil. The Human Development Index (HDI) of the city was estimated at 0.701 and the estimated population is of 100.674 inhabitants [17]. The city has 40 Family Health 
Teams (FHSt), with a percentage of coverage of $100 \%$. The Strengthening the Reporting of Observational Studies in Epidemiology (STROBE) checklist for observational studies was used to help in the research and report the results obtained.

The sample was calculated considering the cross-sectional design using the following parameters: expected proportion of $50 \%$, considering the heterogeneity of the measured variables; maximum sample error of $5 \%$; significance level of $95 \%$. The sample calculation for finite populations indicated the need to include 536 cases; $20 \%$ was added to this value to compensate possible losses, resulting in a final sample size of 670 . To ensure representativeness, a probabilistic sampling stratified by census tract was used. Losses corresponded to individuals who refused to participate and who were not found at home after three attempts at different times and days, which included at least one visit on a weekend.

The study included all individuals living in areas covered by the FHS with age equal to or higher than 6 years, who agreed to participate in the study by signing an Informed Assent Term or an Informed Consent Term. The exclusion criterion was the diagnosis of sensory, motor, cognitive or psychic limitations that prevented the individuals from answering the questions.

\section{Data Collection}

An intensive direct observation technique was used for data collection, through a previously validated form (standardized or structured interview) and consolidated in the Application of Oral Health Services Access in Android operating system. A previous contact was made with the FHSt, to which selected census sectors are ascribed, in order to ask for the possibility of accompanying Community Health Agents (CHA) in visits. Using the software had the advantage of reducing costs, collection time and the possibility of errors in data entry. To ensure data quality and control, researchers underwent training.

Theoretical models suggest that the use of health services occurs according to predisposing factors (sociodemographic and cultural variables, individual attitudes and opinions); enabling factors (availability of health resources and services, income and health insurance); and health needs (self-perception of health) $[14,18]$. After a literature review on the topic, only social and individual variables were chosen for the investigation of their relationship with access to oral health services, including items of the National Household Sample Survey (NHSS) [19] and the Oral Impacts on Daily Performances (OIDP) instrument on self-perception of oral health [20], which are previously validated instruments in the country.

The response (dependent) variable of this study was "Access to oral health actions", categorized as: "Yes", when the participant had used oral health services and accessed oral health promotion and oral disease prevention actions (participation in meetings or lectures about oral health, receipt of brushing kits, use of fluoride, home visits of the oral health team) in the two years prior to interview; "No" when the participant had not received any kind of oral health action or had only used oral health services or only accessed oral health promotion and oral disease prevention actions. The other variables were considered as explanatory (independent) variables, since the main objective of the study was to investigate the socioeconomic and demographic conditions and oral health needs that influenced the access to oral health actions.

The socioeconomic and demographic variables were: sex (male/female); age group (06-14 years/15-24 years/25-49 years/50-64 years/65 years or more); marital status (single/married/divorced/widowed); educational level (illiterate/elementary school/high school/higher education); enrolled in a minimum income program (yes/no); and monthly family income (< 1 minimum wage/ 1 minimum wage/2 minimum wages $/ 3$ minimum wages or more). The independent variables of oral health needs were: self-perception of oral health 
(excellent/very good/good/more or less/bad); toothache ever in life (yes/no); and toothache in the last six months (yes/no). The categorization of variables such as age, educational level and income were used as a strategy to reduce degrees of freedom during the statistical analysis and it was based on previous studies $[11,21]$.

Regarding access to oral health actions, the variables studied were: last visit to the dentist (Less than 1 year/Between 1 and 2 years/3 years or more/Never went to a dentist); type of service most used (private service, health plan, health insurance/public service in the FHS/other public service); access to lectures or meetings on oral health (yes/no); access to brushing kits, educational material or topical application of fluoride (yes/no); visit by CHAs, oral health assistants or dentists with provision of oral health guidelines (yes/no).

\section{Data Analysis}

Initially, a descriptive statistical analysis of all variables was carried out aiming to characterize the sample. Then, bivariate and multivariate analyses were performed. The Pearson's Chi-square test or the Fisher's exact test, when appropriate, was used to identify associations between the outcome and independent variables. Subsequently, the explanatory variables with p-value $<0.25$ in the bivariate analysis or those of epidemiological relevance in the case of the subject in question were incorporated into a multivariate decision tree analysis using the Chi-squared automatic interaction detection (CHAID) algorithm. This approach allows optimizing the process of prediction and identification of the most relevant factors for understanding the outcome studied and may reveal useful patterns that are generally not detected through traditional statistical analysis.

Only the variables that presented p-value $<0.05$ in the chi-square test using the Bonferroni correction were retained in the final diagram of the Decision Tree. Ten subsamples were used to validate the results through the cross-validation procedure and the goodness-of-fit of the models was evaluated through the general risk estimate, which compares the difference between the expected and observed values, indicating to what extent the algorithm correctly predicts the results. All analyses were conducted using the IBM SPSS Statistics software (SPSS for Windows, IBM Corp., version 20.0, Armonk, NY, USA).

\section{Ethical Considerations}

All Brazilian (NHC Resolution/MH n 466/2012) and international (Declaration of Helsinki) precepts on ethics of research involving human beings were respected. The research project was approved by an independent Ethics Committee (CAAE 20260313.1.0000.5187).

\section{Results}

The participation rate in the study was $90.9 \%(\mathrm{n}=609$ individuals $)$. The majority of the participants were female (74.1\%) and in the age group of 25-34 years (44.4\%), ranging in age from 6 to 87 years, married or living with their partners (51 9\%), with primary school education level (43.3\%), not a member of minimum income programs $(77.5 \%)$ and the monthly family income was of three minimum wages or more (30.0\%). Regarding their oral health needs, the majority considered their oral health as good (37.8\%), reported toothache ever in life (84.0\%), and had had no toothache in the last six months (80.7\%) (Table 1).

Table 2 shows the distribution of the sample according to access to oral health actions. Regarding the individuals who had been to the dentist some time in their lives, the majority reported to use private oral health services or health plans (50.3\%). It was noteworthy that most individuals said they had never received 
educational materials or topical application of fluoride $(58.5 \%)$ or a visit from the oral health team or CHAs for guidance in oral health (90.2\%).

Table 1. Participants distribution according to socioeconomic characteristics, self-perception of oral health, and history of toothache.

\begin{tabular}{|c|c|c|}
\hline Variables & $\mathbf{N}$ & $\%$ \\
\hline \multicolumn{3}{|l|}{ Sex } \\
\hline Male & 158 & 25.9 \\
\hline Female & 451 & 74.1 \\
\hline \multicolumn{3}{|l|}{ Age Group } \\
\hline 06-14 Years & 42 & 6.9 \\
\hline 15-24 Years & 72 & 11.8 \\
\hline 25-49 Years & 270 & 44.3 \\
\hline $50-64$ Years & 131 & 21.5 \\
\hline 65 Years or More & 94 & 15.4 \\
\hline \multicolumn{3}{|l|}{ Marital Status } \\
\hline Single & 208 & 34.2 \\
\hline Married & 316 & 51.9 \\
\hline Divorced & 33 & 5.4 \\
\hline Widowed & 52 & 8.5 \\
\hline \multicolumn{3}{|l|}{ Educational Level } \\
\hline Illiterate & 20 & 3.3 \\
\hline Elementary School & 264 & 43.3 \\
\hline High School & 203 & 33.3 \\
\hline Higher Education & 122 & 20.0 \\
\hline \multicolumn{3}{|c|}{ Enrolled in a Minimum Income Program } \\
\hline Yes & 137 & 22.5 \\
\hline No & 472 & 77.5 \\
\hline \multicolumn{3}{|l|}{ Monthly Family Income } \\
\hline$<1 \mathrm{BMW}$ & 95 & 15.6 \\
\hline $1 \mathrm{BMW}$ & 174 & 28.6 \\
\hline 2 BMW & 157 & 25.8 \\
\hline 3 BMW or More & 183 & 30.0 \\
\hline \multicolumn{3}{|l|}{ Self-Perception of Oral Health } \\
\hline Excellent & 42 & 6.9 \\
\hline Very Good & 45 & 7.4 \\
\hline Good & 230 & 37.8 \\
\hline More or Less & 216 & 35.5 \\
\hline Bad & 76 & 12.5 \\
\hline \multicolumn{3}{|l|}{ Toothache Ever in Life } \\
\hline Yes & 508 & 84.0 \\
\hline No & 97 & 16.0 \\
\hline \multicolumn{3}{|l|}{ Toothache in the Last Six Months } \\
\hline Yes & 97 & 19.3 \\
\hline No & 406 & 80.7 \\
\hline
\end{tabular}

BMW: Brazilian Minimum Wage.

Table 2. Participants distribution according to access to oral health actions.

\begin{tabular}{lcc}
\multicolumn{1}{c}{ Variables } & $\mathbf{N}$ & \% \\
\hline Last Visit to Dentist & & \\
Less Than 1 Year & 242 & 39.7 \\
Between 1 and 2 Years & 160 & 26.3 \\
3 Years or More & 202 & 33.2 \\
Never went to a Dentist & 5 & 0.8 \\
Type of Service Most Used & & \\
Private Service, Health Plan, Health Insurance & 300 & 50.3 \\
Public Service in the FHS & 204 & 34.2 \\
Other Public Service & 93 & 15.6
\end{tabular}




\begin{tabular}{|c|c|c|}
\hline \multicolumn{3}{|c|}{ Access to Lectures or Meetings on Oral Health } \\
\hline Yes & 298 & 49.6 \\
\hline No & 303 & 50.4 \\
\hline \multicolumn{3}{|c|}{ Access to Brushing Kits, Educational Material or TAF } \\
\hline Yes & 252 & 41.5 \\
\hline No & 355 & 58.5 \\
\hline \multicolumn{3}{|c|}{ Visit by the Chas, Oral Health Assistants or Dentists } \\
\hline Yes & 59 & 9.8 \\
\hline No & 543 & 90.2 \\
\hline \multicolumn{3}{|c|}{ Full Access to Oral Health Actions } \\
\hline Yes & 280 & 46.0 \\
\hline No & 329 & 54.0 \\
\hline
\end{tabular}

TAF: Topical Application of Fluoride

Table 3 shows the results of the bivariate analysis. There was a statistically significant association between the type of access to oral health actions and age range $(\mathrm{p}<0.001)$, marital status $(\mathrm{p}=0.013)$, educational level $(p<0.001)$, family monthly income $(p<0.001)$, self-perception of oral health $(p=0.007)$ and toothache ever in life $(p=0.001)$. It was observed that the older the age, the lower the access to oral health actions. Regarding income, full access was reached by individuals with 3 minimum wages or more. As for educational level, individuals with more years of study had more access to oral health services. It was also showed an association between self-perception of oral health $(\mathrm{p}=0.028)$, toothache ever in life $(\mathrm{p}=0.012)$, and toothache in the last 6 months $(\mathrm{p}=0.023)$. It was found that those who considered their oral health as excellent or very good and who had never had toothache in life had greater access.

Table 3. Bivariate analysis between access to oral health actions and the independent variables.

\begin{tabular}{|c|c|c|c|c|c|c|c|}
\hline \multirow{3}{*}{ Variables } & \multicolumn{6}{|c|}{ Full Access to Oral Health Actions } & \multirow{3}{*}{ p-value } \\
\hline & \multicolumn{2}{|c|}{ Yes } & \multicolumn{2}{|c|}{ No } & \multicolumn{2}{|c|}{ Total } & \\
\hline & $\mathrm{N}$ & $\%$ & $\mathrm{~N}$ & $\%$ & $\mathrm{~N}$ & $\%$ & \\
\hline Sex & & & & & & & $0.121^{(\mathrm{a})}$ \\
\hline Male & 81 & 51.3 & 77 & 48.7 & 158 & 100.0 & \\
\hline Female & 199 & 44.1 & 252 & 55.9 & 451 & 100.0 & \\
\hline Age Group & & & & & & & $<0.001^{(\mathrm{a}) *}$ \\
\hline 06-14 Years & 30 & 71.4 & 12 & 28.6 & 42 & 100.0 & \\
\hline 15-24 Years & 50 & 69.4 & 22 & 30.6 & 72 & 100.0 & \\
\hline 25-49 Years & 142 & 52.6 & 128 & 47.4 & 270 & 100.0 & \\
\hline 50-64 Years & 45 & 34.4 & 86 & 65.6 & 131 & 100.0 & \\
\hline 65 Years or More & 13 & 13.8 & 81 & 86.2 & 94 & 100.0 & \\
\hline Marital Status & & & & & & & $0.013^{(\mathrm{a}) *}$ \\
\hline Single & 105 & 50.5 & 103 & 49.5 & 208 & 100.0 & \\
\hline Married & 149 & 47.2 & 167 & 52.8 & 316 & 100.0 & \\
\hline Divorced & 12 & 36.4 & 21 & 63.6 & 33 & 100.0 & \\
\hline Widowed & 14 & 26.9 & 38 & 73.1 & 52 & 100.0 & \\
\hline Educational Level & & & & & & & $<0.001^{(\mathrm{b}) *}$ \\
\hline Illiterate & 1 & 5.0 & 19 & 95.0 & 20 & 100.0 & \\
\hline Elementary School & 97 & 36.7 & 167 & 63.3 & 264 & 100.0 & \\
\hline High School & 106 & 52.2 & 97 & 47.8 & 203 & 100.0 & \\
\hline Higher Education & 76 & 62.3 & 46 & 37.7 & 122 & 100.0 & \\
\hline Enrolled in a Minimum Income Program & & & & & & & $0.558^{(\mathrm{a})}$ \\
\hline Yes & 66 & 48.2 & 71 & 51.8 & 137 & 100.0 & \\
\hline No & 214 & 45.3 & 258 & 54.7 & 472 & 100.0 & \\
\hline Monthly Family Income & & & & & & & $<0.001^{(\mathrm{a}) *}$ \\
\hline$<1 \mathrm{BMW}$ & 39 & 41.1 & 56 & 58.9 & 95 & 100.0 & \\
\hline $1 \mathrm{BMW}$ & 74 & 42.5 & 100 & 57.5 & 174 & 100.0 & \\
\hline 2 BMW & 56 & 35.7 & 101 & 64.3 & 157 & 100.0 & \\
\hline 3 BMW & 111 & 60.7 & 72 & 39.3 & 183 & 100.0 & \\
\hline Self-Perception of Oral Health & & & & & & & $0.007^{(\mathrm{a}) *}$ \\
\hline
\end{tabular}




\begin{tabular}{|c|c|c|c|c|c|c|c|}
\hline Excellent & 23 & 54.8 & 19 & 45.2 & 42 & 100.0 & \\
\hline Very Good & 28 & 62.2 & 17 & 37.8 & 45 & 100.0 & \\
\hline Good & 110 & 47.8 & 120 & 52.2 & 230 & 100.0 & \\
\hline More or Less & 96 & 44.4 & 120 & 55.6 & 216 & 100.0 & \\
\hline Bad & 23 & 30.3 & 53 & 69.7 & 76 & 100.0 & \\
\hline Toothache Ever in Life & & & & & & & $0.001^{(\mathrm{a}) *}$ \\
\hline Yes & 219 & 43.1 & 289 & 56.9 & 508 & 100.0 & \\
\hline No & 59 & 60.8 & 38 & 39.2 & 97 & 100.0 & \\
\hline Toothache in the Last Six Months & & & & & & & $0.057^{(a)}$ \\
\hline Yes & 50 & 51.5 & 47 & 48.5 & 97 & 100.0 & \\
\hline No & 166 & 40.9 & 240 & 59.1 & 406 & 100.0 & \\
\hline
\end{tabular}

BMW: Brazilian Minimum Wage; (a)Pearson's Chi-square test; (b)Fischer's exact test; *Statistically Significant.

Figure 1 shows the results of the multivariate analysis using the decision-tree based CHAID for the pattern of access to oral health actions, adjusted for the factors investigated. The final model showed that the variables with the most relevant role in the access to oral health actions were: age group (adjusted p-value $<0.001$ ), educational level (adjusted p-value in Node $4=0.009$; adjusted p-value in Node $5=0.005$ ), and selfperception of oral health (adjusted p-value $=0.001)$.

The assessment of the root nodes until reaching the terminal nodes or leaves (where the probable decision is found) revealed two main findings: 1) there was an association between full access to oral health actions, younger age groups, higher education level, and good, very good or excellent self-perception of oral health; 2) there was an association between partial or non-existent access to oral health actions, older age groups, lower educational level and more or less or bad self-perception of oral health.

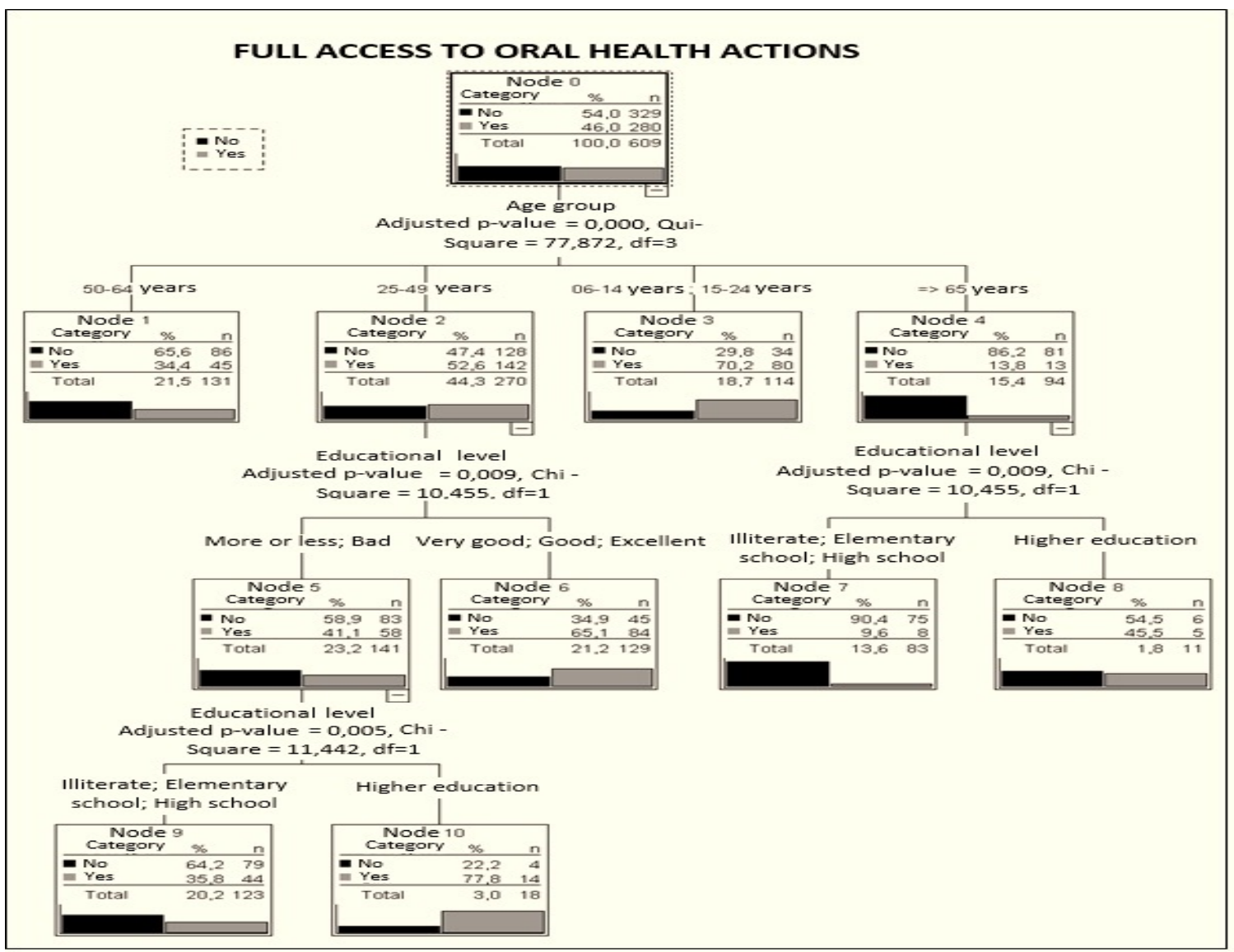

Figure 1. Multivariate analysis according to decision-tree based Chi-squared automatic interaction detection (CHAID) for the pattern of access to oral health actions, adjusted by investigated factors. 


\section{Discussion}

Access to oral health services has increased in the country due to the rise of coverage and provision of private and public services and average income of the population. However, this has been preceded by historical inequalities $[7,8,16]$ that hindered the comprehensive provision access to health care, consequently not meeting people's needs, and causing a reflection on their precarious health conditions [2,22].

Among the initiatives chosen to expand the coverage of access to public oral health services, the insertion of oral health teams in the FHS stands out as a way to reduce health inequalities, because FHSt act closer to the reality of the population served [23]. This made it possible a care proposal with a collective scope and focused on oral health promotion and disease prevention practices, contributing to integrality of health care $[1,23,24]$.

In the present study, despite the fact that the city has $100 \%$ coverage of oral health services, a higher use of private over public services was observed, corroborating with national surveys [8,16]. Availability is one of the most important characteristics for access to health services, but it has not; however, represent changes in the care process itself. More planning and organization of teams is needed [6,7,9,23]. The literature points to several organizational barriers that can influence this access, such as travel time, days and shifts of operation, and scheduling type [25-27]. Characteristics of health services that could justify the lower utilization of public services were not analyzed in the present study.

The fact that the interviewees have low access to oral health promotion and disease prevention actions is alarming, especially because these actions must be prioritized in the scope of the FHS [28]. They should enhance the change of the care model proposed by the NOHP, guiding care towards the principle of integrality, besides providing stronger bonds between users and FHSt [29]. It should also be considered that home visits are not part of the daily routine of the City's oral health teams, a mandatory aspect for professionals of the FHS, whose proposal is to extend health practices to family's homes and communities [30].

It was proposed an explanatory model of access in which the use of services is a result of individual variables divided into factors of predisposition, enabling resources and needs [31]. According to this model, the individual variables of predisposition that influenced access were age and educational level, while selfperception of oral health was related to needs.

Regarding the association with age, the oral health care model in Brazil is markedly focused on age groups of schoolchildren. Despite the demographic transition in the country, with the increase in number of elderly people, this population has not been prioritized in the planning and execution of actions yet [13].

In the present study, the percentage of elderly people who did not have access to oral health actions was high. It is important to emphasize that elderly individuals also present a higher prevalence of oral problems and dental losses [32] that generate negative impacts on oral health. This comes also from difficulties of access and absence of specific oral health programs for this public, which can be considered a serious public health problem [33].

Research shows that the more years of schooling of the individuals or of their household heads, the greater was the use of health services [11,16,34]. Some scholars explain that income and educational level are closely related to socioeconomic characteristics, higher the educational levels are related to higher average income and better capacity to pay for services [35]. A higher educational level also increases access to information, a better understanding of needs and, therefore, more conditions to face barriers to access [2].

Regarding self-perception of oral health, it was found that individuals who showed a better perception of their teeth and mouth health had more access to actions than those who perceived it as bad. This assessment 
of health status is directly influenced by past experiences, individual habits and by the cultural and social environment in which individuals are inserted [36].

The individuals' self-perceived health is also related to perceived needs and can be an indicator of how such needs impact on access to oral health services. It is also important to understand why people seek for services, since needs are transformed into demands and these, into use of services [37].

Despite the advances related to the expansion of access to oral health services at the national level, it is still not possible to guarantee equity and integrality of care. Increasing the coverage of oral health teams does not always represent changes in the work process and much is still necessary to reduce inequities and increase the access to health promotion and disease prevention actions in the city in question.

Due to the cross-sectional nature of this investigation, reverse causality must be taken into account in the explanation of the findings, as well as the possibility of the individuals' responses being subject to memory and information bias. A series of measures were taken to try to decrease these events, such as the realization of a pilot study and use of previously validated forms. Regarding memory bias, in order to try to reduce its occurrence, access was only considered when the individuals reported the use of oral health services in the two years prior to the interview.

Although restricted to a medium-sized city, the present study allows discussing a topic of great importance to reorient oral health care practices in the FHS. It was also possible to investigate the access to oral health actions according to social and individual determinants through decision-tree based data modeling. Finally, the study was representative of the reference population, generating useful information to guide strategic planning, reformulation of care practices and development of oral health actions. Future studies must assess the association between individual factors and external factors such as availability of services and professionals, geographical barriers and the organization of services.

\section{Conclusion}

The results suggest that access to oral health actions may be associated with educational level, age and self-perception of oral health. Despite the considerable use of oral health services, much is still necessary to reduce health inequities because access to oral health actions, including promotion and prevention actions, does not occur in an equitable way. This access is marked by intense social inequalities, favoring plots of population that live better situations to the detriment of those with the greater needs, such as people with lower education level, lower income, and elderly people.

\section{Authors' Contributions}

\begin{tabular}{|c|c|c|}
\hline DEWF & (iD) $0000-0001-7680-0387$ & $\begin{array}{l}\text { Conceptualization, Methodology, Investigation, Formal Analysis, Writing - } \\
\text { Original Draft Preparation and Writing - Review and Editing. }\end{array}$ \\
\hline RSCS & (iD) $0000-0001-5213-3698$ & $\begin{array}{l}\text { Conceptualization, Methodology, Formal Analysis, Writing - Original Draft } \\
\text { Preparation and Writing - Review and Editing. }\end{array}$ \\
\hline RCRM & (iD) $0000-0001-7268-1202$ & Conceptualization, Methodology and Writing - Review and Editing. \\
\hline ASS & (iD) $0000-0002-2269-7967$ & Investigation and Writing - Review and Editing. \\
\hline VAM & (iD) $0000-0002-0642-2373$ & Investigation and Writing - Review and Editing. \\
\hline AMML & (iD) 0000-0003-1053-0534 & Investigation and Writing - Review and Editing. \\
\hline AMAM & (iD) $0000-0003-2651-7836$ & Formal Analysis and Writing - Review and Editing. \\
\hline IMB & (iD) $0000-0003-4750-5666$ & Formal Analysis and Writing - Review and Editing. \\
\hline $\mathrm{AMRC}$ & (iD) $0000-0002-2682-1048$ & Formal Analysis and Writing - Review and Editing. \\
\hline ALC & (iD 0000-0003-3572-3332 & Conceptualization, Methodology and Writing - Review and Editing. \\
\hline
\end{tabular}




\section{Financial Support}

Research Program for the Unified Health System (PPSUS) / The Brazilian National Council for Scientific and Technological Development - CNPQ / Fundação de Apoio à Pesquisa do Estado da Paraíba - FAPESQ (Project No. 044/13 - Notice 001/2013 - Agreement SINCOV 774379/2012).

\section{Conflict of Interest}

The authors declare no conflicts of interest.

\section{References}

[1] Antunes JLF, Narvai PC. Dental health policies in Brazil and their impact on health inequalities. Rev Saúde Pública 2010; 44(2):360-5. https://doi.org/10.1590/S0034-89102010005000002

[2] Soares FF, Chaves SCL, Cangussu MCT. Local government and public dental health services: an analysis of inequality in use. Cad Saúde Pública 2015; 31(3):586-96. https://doi.org/10.1590/0102-311 x00077214

[3] Viacava F, Oliveira RAD, Carvalho CC, Laguardia J, Bellido JG. SUS: supply, access to and use of health services over the last 30 years. Ciênc. Saúde Coletiva 2018; 23(6):1751-62. https://doi.org/10.1590/1413-81232018236.06022018

[4] Brasil. Constituição (1988). Constituição da República Federativa do Brasil. Brasília: Senado Federal, 1988. Available from: https://www2.senado.leg.br/bdsf/bitstream/handle/id/508200/CF88_EC85.pdf? sequence=1 [Accessed on July 07, 2018]. [In Portuguese]

[5] Brasil, Ministério da Saúde. Diretrizes da Política Nacional de Saúde Bucal. Brasília: Ministério da Saúde, 2004. Available from: http://189.28.128.100/dab/docs/publicacoes/geral/diretrizes_da_politica_nacional_de_saude_ bucal.pdf. [Accessed on July 07, 2018]. [In Portuguese]

[6] Carnut L, Filgueiras LV, Figueiredo N. Goes PSA. Initial validation of the index of oral healtcare needs for oral health teams in the family healthcare strategy. Ciênc Saúde Coletiva 2011; 16(7):3083-91. https://doi.org/10.1590/S1413-81232011000800008

[7] Rocha RACP, Goes PSA. Comparison of access to Oral Health Services between areas covered and not covered by the Family Health Program in Campina Grande, Paraíba State, Brazil. Cad Saúde Pública 2008; 24(12):2871-80. https://doi.org/10.1590/S0102-311X2008001200016

[8] Barros AJD, Bertoldi AD. Inequalities in utilization and access to dental services: a nationwide assessment. Ciênc Saúde Coletiva 2002; 7(4):709-17. https://doi.org/10.1590/S1413-81232002000400008

[9] Cavalcanti RP, Gaspar GS, Goes PSA. Use and access to oral health services of SUS - a comparison between rural and urban populations. Pesqui Bras Odontopediatria Clín Integr 2012; 12(1):121-6. https://doi.org/10.4034/PBOCI.2012.121.19

[10] Esposti CDD, Cavaca AG, Côco LSA, Santos-Neto ET, Oliveira AE. Dimensions of oral health services access in printed media. Saúde Soc 2016; 25(1):19-30. https://doi.org/10.1590/So104-12902016141706

[11] Madruga RCR, Soares RSC, Cardoso AMR, Cavalcanti SDLB, Goes PSA, Cavalcanti AL. Access to oral health services in areas covered by the family health strategy, Paraíba, Brazil. Pesqui Bras Odontopediatria Clín Integr 2017; 17(1):1-10. http://dx.doi.org/10.4034/PBOCI.2017.171.06

[12] Buss PM, Pellegrini Filho A. A saúde e seus determinantes sociais. Physis: Rev Saúde Coletiva 2007; 17(1):77-93. https://doi.org/10.1590/So103-73312007000100006 [In Portuguese]

[13] Baldani MH, Brito WH, Lawder JAC, Mendes YBE, Silva FFM, Antunes JLF. Individual determinants of dental care utilization among low-income adult and elderly individuals. Rev Bras Epidemiol 2010; 13(1):150-62. https://doi.org/10.1590/S1415-790X2010000100014

[14] Andersen RM. Revisiting the behavioral model and access to medical care: does it matter? J Health Soc Behav 1995; 36:1-10. https://doi.org/10.2307/2137284

[15] Peres MA, Iser BPM, Boing AF, Yokota RTC, Malta DC, Peres KG. Inequalities in access to and utilization of dental care in Brazil: an analysis of the Telephone Survey Surveillance System for Risk and Protective Factors for Chronic Diseases (VIGITEL 2009). Cad Saúde Pública 2012; 28(Suppl):90-100.

https://doi.org/10.1590/So102-311X2012001300010

[16] Peres KG, Peres MA, Boing AF, Bertoldi AD, Bastos JL, Barros AJD. Reduction of social inequalities in utilization of dental care in Brazil from 1998 to 2008. Rev Saúde Pública 2012; 46(2):250-8.

https://doi.org/10.1590/S0034-89102012000200007

[17] Instituto Brasileiro de Geografia e Estatística. Diretoria de Pesquisas, Coordenação de População e Indicadores Sociais. Estimativas da população residente nos municípios brasileiros com data em $1^{\circ}$ de julho de 2016 . Estimativa da população de Patos-PB. Available from: http://www.ibge.gov.br/home/estatistica/populacao/estimativa2016/ estimativa_tcu.shtm. [Accessed on July 07, 2018]. [In Portuguese]

[18] Travassos C, Castro MSM. Determinantes e desigualdades sociais no acesso e na utilização de serviços de saúde. In: Giovanela L, Escorel S, Lobato LVC, Noronha JC, Carvalho AI. Políticas e Sistemas de Saúde no Brasil. 2nd. ed. Rio de Janeiro: Fiocruz; 2015. [In Portuguese] 
[19] Instituto Brasileiro de Geografia e Estatística. Diretoria de Pesquisas, Coordenação de Trabalho e Rendimento. Acesso e utilização de serviços de saúde. PNAD 2003. Rio de Janeiro: Instituto Brasileiro de Geografia e Estatística, 2005. Available from: https://biblioteca.ibge.gov.br/visualizacao/livros/liv6194.pdf. [Accessed on July 02, 2018]. [In Portuguese]

[20] Goes PSA. The prevalence and impact of dental pain in Brazilian schoolchildren and their families [Thesis]. London: University of London; 2001. 305p.

[21] Pinheiro RS, Viacava F, Travassos C, Brito AS. Gender, morbidity, access and utilization of health services in Brazil. Ciênc Saúde Coletiva 2002; 7(4):687-707. https://doi.org/10.1590/S1413-81232002000400007

[22] Motta LJ, Pissinato AVS, Pinto MM, Monken SF. Oral health index associated with socioeconomic indicators in brazil from 1986 to 2010. Econ Gest 2015; 16(42):138-52. https://doi.org/10.5752/P.1984-6606.2016v16n42p138

[23] Sanchez HF, Braga SC. Improving access to Oral Health in the Family Health Strategy: a literature review. Rev APS 2014; 17(3):397-402.

[24] Aquilante AG, Aciole GG. Oral health care after the National Policy on Oral Health - "Smiling Brazil": a case study. Ciênc Saúde Coletiva 2015; 20(1):239-48. https://doi.org/10.1590/1413-81232014201.21192013

[25] Assis MMA, Jesus WLA. Access to health services: approaches, concepts, policies and analysis model. Ciênc Saúde Coletiva 2012; 17(11):2865-75. https://doi.org/10.1590/S1413-81232012001100002.

[26] Travassos C, Martins M. A review of concepts in health services access and utilization. Cad Saúde Pública 2004; 20(Sup2):190-8. https://doi.org/10.1590/So 102-311X2004000800014

[27] Oliveira LH, Mattos RA, Souza AIS. Travelling citizens: the "users" of the Brazilian Unified Health System and the meanings of its demand to the health care emergency services in the context of a process of assistential model reorientation. Ciênc Saúde Coletiva 2009; 14(5):1929-38. https://doi.org/10.1590/S1413-81232009000500035

[28] Mattos GCM, Ferreira EF, Leite ICG, Greco RM. The inclusion of the oral health team in the Brazilian Family Health Strategy: barriers, advances and challenges. Ciênc Saúde Coletiva 2014; 19(2):373-82. https://doi.org/10.1590/1413-81232014192.21652012

[29] Lima ACS, Cabral ED, Vasconcelos MVB. Patient satisfaction at Specialized Dental Clinics in Recife, Pernambuco State, Brazil. Cad Saúde Pública 2010; 26(5):991-1002. https://doi.org/10.1590/So102-311X2010000500021

[30] Giacomozil CM, Lacerda MR. The practice of home assistance by family health strategy professionals. Texto Contexto Enferm 2006; 15(4):645-53. https://doi.org/10.1590/S0 104-07072006000400013

[31] Andersen RM. National health surveys and the behavioral model of health services use. Med Care 2008; 46(7):647-53. https://doi.org/10.1097/MLR.obo13e31817a835d

[32] Brasil. Ministério da Saúde. SB Brasil 2010: Pesquisa Nacional de Saúde Bucal: Resultados Principais. Brasília: Ministério da Saúde; 2012. Available from: http://bvsms.saude.gov.br/bvs/publicacoes/pesquisa_nacional_ saude_bucal.pdf. [Accessed on July 10, 2018]. [In Portuguese]

[33] Rosendo RA, Souza JNL, Abrantes JGS, Cavalcante ABP, Ferreira AKTF. Self-perception of the oral health and its impact in elderly people's life quality: a literature review. RSC Online 2017; 6(1):89-102.

[34] Jornada B, Santos BZ, Garcia LP, Dalpian DM, Backes DS, Krause LF. Access and use of dental services among adolescents and associated factors in Brazil. Discip Scie 2012; 13(2):275-88.

[35] Pinto RS, Matos DL, Loyola-Filho AI. Characteristics associated with the use of dental services by the adult Brazilian population. Ciênc Saúde Coletiva 2012; 17(2):531-44. https://doi.org/10.1590/S1413-81232012000200026

[36] Ayach C. A visão do usuário sobre o serviço público odontológico e a autopercepção em saúde bucal [Thesis]. São Paulo: Faculdade de Odontologia de Araçatuba, Universidade Estadual Paulista; 2015. 122p. [In Portuguese]

[37] Pinheiro RS, Torres TZG. Access to oral health services between Brazilian States. Ciênc Saúde Coletiva 2006; 11(42):999-1010. https://doi.org/10.1590/S1413-8123200600040002 1 